\title{
UNIVERSITY AS AN ACTOR OF A REGIONAL DEVELOPMENT PROCESSES: PRACTICES OF THE SOUTHERN FEDERAL DISTRICT OF RUSSIA
}

\author{
EvgENy Kolbachev ${ }^{1}$
}

Southern-Russian State Polytechnical University (Russia)

\begin{abstract}
Author analyzed the ways of overcoming the negative tendency to the degradation of the human capital in the provincial regions of Russia and other countries of the Eastern Europe. It's shown that the important role in the processes of solving the problem should be played by the technical universities, situated in the small towns of the region. The development of the universities should be carried on according to the specific strategy, which's goal is a training of the qualified specialists, and to take as the students the local young people, which are going to live and get a job in the region in future. There are also presented a set of requirements for this kind of the strategy, which are based on the idea of the institutional projecting of the University Technopolis.

KEY WORDS: higher education, human capital, institutional designing, regional development, technopolis.
\end{abstract}

JEL CODES: R110, I230, I250

DOI: http://dx.doi.org/10.15181/rfds.v14i3.870

\section{Introduction}

Problem. The countries of the Eastern Europe and Russia in the last two decades show the tendencies to decreasing a quality level of the human capital. The numerous researches analyzed the different aspects of the problem, such as: the demographic setting (Anderson, 2002); investment in the human resources (Tondl, 2003: 35); role of the human capital and level of the management quality, as a reason for the appearance of the gap in production level indexes between the Eastern and Western Europe (Steffen, 2008: 19). All of them agree, that the main reasons for the mentioned problems are the features of the transition from the totalitarian society to the societies, based on the mechanisms of the market economy (that differ in one country from another), and the influence of the worldwide globalization processes.

In the regions of Russian provinces the basic reasons for the degradation of the human capital are the following:

- a considerable decreasing of the professional activities' creativity of the substantial percent of the population, the reasons for which are the laying of the numerous high-technology production enterprises and people's leaving a creative sphere for the primitive commerce, government service, office work and other activities with a low level of the intellectual and creative component;

1 Evgeny Kolbachev - doctor of economic sciences, professor, Head of the Department of Production and innovation management, Southern-Russian State Polytechnical University (NPI). Scientific field: institutional and evolution economy, human capital, innovation management

Te.: +79185519699

E-mail: kolbachev@yandex.ru 
- decreasing of the efficiency and effectiveness level of the universal secondary education and substitution of the educational values by the pupils' preparation for the primitive Concluding State Attestation procedure as a goal;

- decreasing of the effectiveness level of higher and secondary professional education: the reason for such tendency is the job shortage in the high-technology sphere and disbelief of the substantial percent of students in the prospects of getting a job, which would answer the student's special subject (Kolbachev, 2012: 7).

Besides the aforesaid, in the last decades in Russia increases the level of the inequality in a property status as a key social stratification, and a gap between the life quality and development prospects level between the people of the capital and the cities, and the people from provinces (small towns and villages), also increased the people's outflow level (first of all - the most educated part of them) from the provinces to the cities, and the flight of the human capital. The reason is the dislocation of the majority of the higher professional education institutions in the capital and the cities, as the hands-on experience in the Soviet period (Gerrber, 1995: 49).

Purpose. The research purpose is the formation of the Development Strategies of the Universities and other higher education institutions which should do their best in covering the region's social demands. The information that can be obtained as a result of the research should be used to improve the theory of the regions' educational institutions strategic development.

Object. The research object is the employees structure of the enterprises, universities and other higher education institutions in the Southern Federal District of Russia.

Tasks. The tasks of the article are the research of the region's employees educational level; the analysis of the social role played by the Technical University in the region; the application of the institutional approach to the Technical University Development Strategy; the consideration of the Technical University as a part of the regional innovation system and the formation of its Development Strategy.

Methods. The major research methods adopted by the author's scientific work are the descriptive method, typical for social and economic sciences, the method of analysis and synthesis. Author also use a human capital theory (Becker, 1991: 26), theory of the firm (Coase, 1992: 6; Williamson, 1970: 135), the triple helix theory (Shinn, 2002: 15) and the institutional designing methodology (Gooding, 1996: 62). For the empirical studies author used common statistical methods.

\section{Education of the region's employees}

We investigated some of the significant features of the professionals' educations. All of the investigation participants are the employees at the enterprises of the Southern Federal District of Russia. The numerous enterprises are situated in the Rostov region, Volgograd region, Krasnodar krai, and Adygeya Republic. There was examined the education of 1545 professionals of 81 enterprise. This number of the participants and enterprises means that the results of the research are representative.

There were investigated the big enterprises and business groups with more than 1000 employees. The exception was made for the finance organizations (the most of them are the regional branches of the commercial banks and finance companies with the All-Russian volume of activity), and also for some small trade enterprises. The "Mechanical engineering" group of the enterprises includes also the enterprises of the metallurgy and metal working industry, the "Chemical industry group" includes the cement production and production of the building materials. More than a half of the enterprises, which's employees took part in the investigation, are situated in the small towns of the Southern Federal District of Russia.

A special attention is paid to the professionals, which are the graduates of the higher education institution of the Southern Federal District of Russia. We also demonstrate the difference between the graduates, who studied in the higher education institutions of the cities (regions' centers) and ones who studied in the towns 
of middle and small size. As the regions' centers of the Southern Federal District of Russia we assigned Rostov-on-Don, Krasnodar and Volgograd. The most of the regions' universities and other higher education institutions are situated in these three cities.

In the table 1 we present a structure of the enterprises' employees, based on the location of the institution, where they got their professional education. In the table 2 there is information about how the employees' professional activity conforms to their graduates' chief subject.

According to the information in the tables, we can make a conclusion, that the most of the regional enterprises' employees are also the graduates of the higher education institutions of the same region. The number of the Moscow and Saint-Petersburg universities' graduates at the enterprises of the region is very small. It's the prove for the above said idea that the students of these universities don't see any reasons for getting jobs in provinces (even if the provinces is their birthplace).

All of the professionals, who got their educations in the institutions of the foreign countries, are the graduates of the higher education institutions, situated in the post-Soviet independent states (the former republics of the USSR). There weren't any graduates of the universities of other foreign countries among the participants of the investigation.

An overwhelming majority of the professionals, working at the agriculture enterprises, are the graduates of the higher education institutions of the small towns. It is the result of traditional Soviet Union's and Russia's policy: the most of the agricultural educational institutions in the country are situated not in the cities, but in the towns of the province. Authors consider it as a right political decision.

The object of our special interest is the information, presented in the table 2 . The table shows, that a significant amount of the specialists at the enterprises got the jobs, which greatly differ from the special subject that they studied in the higher education institution. One of the reasons of that is the people's inability to get a job that was coinciding with their special subject, in their home region, and changing a place of living to get a job is not typical for Russians' national traditions (Heleniak, 2012: 98). In other hand, a meaningful number of these specialists later got a postgraduate education, some of them - in the educational institutions of the foreign countries.

\section{Social role, played by the Technical University in the region}

The basic tasks, that should be accomplished to solve the above-mentioned problems, are the tasks of encouraging the youth's creative initiatives. The development of such activities is a way to building a new system of values and life goals.

The University, if it's placed in the provinces, is the best fit educational institution for this kind of development, because of its key competences and other features of the activities. First of all, we speak about the "classical" University, which's curriculum is based on the ideas of natural science, technical University, and other institutions of the higher professional education. The graduates of these institutions then become the employees in the real sector of the economy.

The high enough level of the people's intellectual potential and especially increasing of this level is possible if the professional activities in the regions of the country become more creative. To develop the creativeness, in the real sector of economy should appear the new high-technology production systems and the existing productions should be modernized (the base for the modernization is to be made up of the modern technological and organizational knowledge). And the graduates of the regional educational institutions should get the jobs in these production systems.

Technical University is able to develop the important competences for this kind of workers, further the appearance of the high-technology production systems, and carry out the scientific researches and design projects $(\mathrm{R} \& \mathrm{D})$. Working out a curriculum on the base of these knowledge, and using it for teaching the students makes the University a place of forming the professional community for the high-technology productions. 
Table 1. Description of the employees of the enterprises in the Southern Federal District of Russia as of the Higher Education Institutions graduates

\begin{tabular}{|c|c|c|c|c|c|c|}
\hline \multirow{2}{*}{$\begin{array}{l}\text { Sector of } \\
\text { the national } \\
\text { economy }\end{array}$} & \multirow{2}{*}{$\begin{array}{c}\text { Number } \\
\text { of the } \\
\text { exami-ned } \\
\text { enterprises }\end{array}$} & \multicolumn{5}{|c|}{ Percent of the employees, which are the graduates of: } \\
\hline & & $\begin{array}{c}\text { The } \\
\text { institutions } \\
\text { of higher } \\
\text { education } \\
\text { in Moscow } \\
\text { and Saint- } \\
\text { Petersburg }\end{array}$ & $\begin{array}{c}\text { The } \\
\text { institutions } \\
\text { of higher } \\
\text { education in } \\
\text { the cities of } \\
\text { the Southern } \\
\text { Federal } \\
\text { District }\end{array}$ & $\begin{array}{c}\text { The } \\
\text { institutions } \\
\text { of higher } \\
\text { education in } \\
\text { the towns of } \\
\text { the Southern } \\
\text { Federal } \\
\text { District }\end{array}$ & \begin{tabular}{|c|} 
The institutions \\
of higher \\
education in the \\
other regions of \\
Russia
\end{tabular} & $\begin{array}{c}\text { The } \\
\text { institutions } \\
\text { of higher } \\
\text { education } \\
\text { in the } \\
\text { foreign } \\
\text { countries }\end{array}$ \\
\hline \multicolumn{7}{|c|}{ Engineering and production departments } \\
\hline $\begin{array}{l}\text { Mechanical } \\
\text { engineering }\end{array}$ & 11 & 1.3 & 32.4 & 38.3 & 22.3 & 5.7 \\
\hline $\begin{array}{l}\text { Chemical } \\
\text { industry }\end{array}$ & 9 & 2.1 & 19.4 & 36.9 & 24.4 & 17.2 \\
\hline Food industry & 10 & 0.3 & 18.4 & 38.1 & 12.3 & 7.1 \\
\hline Agriculture & 12 & 0.6 & 12.3 & 58.4 & 15.6 & 13.1 \\
\hline Building & 7 & 0.7 & 21.2 & 53.1 & 14.3 & 10.7 \\
\hline Transportation & 8 & 0.5 & 21.4 & 56.7 & 12.1 & 9.3 \\
\hline Trading & 11 & 0.6 & 24.2 & 49.3 & 13.6 & 12.3 \\
\hline $\begin{array}{l}\text { Finance } \\
\text { organizations }\end{array}$ & 13 & 1.3 & 37.4 & 32.2 & 21.2 & 7.9 \\
\hline \multicolumn{7}{|c|}{ Economic and marketing departments } \\
\hline $\begin{array}{l}\text { Mechanical } \\
\text { engineering }\end{array}$ & 11 & 0.9 & 25.4 & 31.3 & 18.4 & \\
\hline $\begin{array}{l}\text { Chemical } \\
\text { industry }\end{array}$ & 9 & 1.1 & 26.4 & 30.5 & 19.2 & 22.8 \\
\hline Food industry & 10 & 0.6 & 21.3 & 32.0 & 16.3 & 29.8 \\
\hline Agriculture & 12 & 0.1 & 18.4 & 40.1 & 13.4 & 28 \\
\hline Building & 7 & 0.4 & 19.3 & 41.2 & 22.3 & 16.8 \\
\hline Transportation & 8 & 0.5 & 18.7 & 43.1 & 26.1 & 11.6 \\
\hline Trading & 11 & 0.6 & 20.1 & 47.4 & 20.1 & 11.8 \\
\hline $\begin{array}{l}\text { Finance } \\
\text { organizations }\end{array}$ & 13 & 0.9 & 19.8 & 30.6 & 19.1 & 29.60 .2 \\
\hline \multicolumn{7}{|c|}{ Managers } \\
\hline $\begin{array}{l}\text { Mechanical } \\
\text { engineering }\end{array}$ & 11 & 0.2 & 20.3 & 51.7 & 17.3 & 10.5 \\
\hline $\begin{array}{l}\text { Chemical } \\
\text { industry }\end{array}$ & 9 & 0.3 & 21.1 & 45.7 & 21.1 & 11.8 \\
\hline Food industry & 10 & 0.2 & 20.1 & 46.9 & 20.1 & 12.7 \\
\hline Agriculture & 12 & 0.1 & 19.3 & 65.9 & 10.3 & 4.4 \\
\hline Building & 7 & 0.2 & 20.3 & 51.8 & 17.9 & 9.8 \\
\hline Transportation & 8 & 0.3 & 19.2 & 49.3 & 20.3 & 10.9 \\
\hline Trading & 11 & 0.1 & 38.2 & 51.6 & 17.3 & 10.4 \\
\hline $\begin{array}{l}\text { Finance } \\
\text { organizations }\end{array}$ & 13 & 0.2 & 39.3 & 32.7 & 19.3 & 8.5 \\
\hline
\end{tabular}

As a result, the region should get a balance between the number of the jobs in the high-technology production sphere and the number of the graduates, whose professional thesaurus is sufficient, and who can become the employees of the new production systems.

Technical University's key competences also give a possibility to increase the quality level of the general secondary education in the region, and contribute to the revival of the secondary education's "enlightening" mission. This mission includes, first of all, the special attention, paid to teaching the natural science 
and mathematics, and preparing the youth for the future work in the real sector of the economy. The young people should be the ones, who will continue the education as the students in the colleges and Universities, and then become the specialists to get the "creative jobs" in the production and other sectors of the national economy.

Table 2. Description of the employees of the enterprises in the Southern Federal District of Russia: how the graduates' chief subject answers the purpose of their professional activity

\begin{tabular}{|c|c|c|c|c|}
\hline \multirow[t]{2}{*}{$\begin{array}{l}\text { Sector of the national } \\
\text { economy }\end{array}$} & \multicolumn{4}{|c|}{$\begin{array}{l}\text { Percent of the employees, and how their chief subject answers the purpose } \\
\text { of the professional activity }\end{array}$} \\
\hline & $\begin{array}{c}\text { Completely } \\
\text { answers }\end{array}$ & $\begin{array}{r}\text { Partially } \\
\text { answers }\end{array}$ & Doesn't answer & $\begin{array}{c}\text { Answers because of the post } \\
\text { graduate education }\end{array}$ \\
\hline Mechanical engineering & 29 & 28 & 22 & 21 \\
\hline Chemical industry & 34 & 23 & 12 & 31 \\
\hline Food industry & 19 & 25 & 39 & 17 \\
\hline Agriculture & 17 & 27 & 47 & 9 \\
\hline Building & 20 & 24 & 33 & 23 \\
\hline Transportation & 19 & 27 & 32 & 22 \\
\hline Trading & 7 & 24 & 46 & 23 \\
\hline Finance organizations & 21 & 23 & 8 & 48 \\
\hline
\end{tabular}

Training of the engineering personnel in the technical University may be joined to the exercises in the economy, management and law. This "union" should be a step to creating a community of managers, which's fundamental education, is engineering, and the "extra" complementary education is management. The effectiveness of this kind of people is the highest when their job is to manage the economy or the government agency, because the most of them are experienced in creative production activities (and this experience they can get during their University studies).

Solving the problem of increasing region's human capital level is also a way to the intensifying of the innovation activities, increasing the level of the regional economy's competitiveness and promotes the social stability.

Technical University, if it's placed in the provinces and covers the regional requirements, becomes a means to fight the social disunity, decrease the gap in the life quality level and possibilities, given to the people of the capitals and cities, and of the towns and villages. It also helps to decrease the outflow of the young people (first of all - the most promising of them) from the provinces to the cities, and the flight of the human capital. These young people will study not far from their native lands, in the usual social and cultural environment. Intellectual growth of the young people in the provinces and creating the facilities for their development should also promote the homecoming of the people, who left the region for the capital, other cities, or left aboard.

The interaction between the technical and economic principles of the engineering economy is a reason for the appearance of the synergistic effects, which enrich both the economic and the engineering scientific approaches. Using of the engineering methods (based on natural science) in the economic solutions makes these solutions more constructive, creative and gives a chance to make manager's work not resemblance to a primitive money-grabbing. In other hand, using the economic criteria for the economic decision-making increases the efficiency of these decisions, and makes them more competitive.

Solving of these problems is contingent on the successful development of the engineering and management personnel, which personnel should be able to accept the challenges of the nowadays economy. The basic "source" of this kind of personnel is the higher education institutions" graduates.

\section{Development Strategy of the Technical University: The institutional approach}

Working out a development strategy for the technical University should be based on the understanding of their major task: generating a new knowledge; and the universities themselves should be regarded as an 
important part of the national and regional innovation systems.

The efficient generating of the new knowledge in general, and specially in the technical University, requires the appropriate institutional environment. This environment is to be developed in conformity with the strategic goals and tasks. Following the ideas, presented in the well-known work (Reichert, 2006: 48), we assert that working out a development strategy of the technical University is a particular case of the institutional designing - a special kind of activity, which's goal is creating or transformation of the institutional environment.

There is a well-known approach to understanding the innovations (Barras, 1990: 24), which is based on the idea of the firm as of the main source of the innovations. That's why, studying the generating of the new knowledge as a part of the firms' activities is said as the most important task. This approach may be interpreted as an idea that generating of the new knowledge is a business process only, but it is a mistake. Technical University's activities are the example of the different way of the knowledge generating.

In actual fact, technical University, as a non-commercial organization, generates a great volume of the new knowledge during its research, innovation and educational activities. But the innovations, which appear as a result of these activities, require the complex of special measures to be commercialized and introduced as a part of the production and business processes by the commercial organizations (Gomulka, 1990: 238).

In the other hand, this problem may be considered in a different ways, if we pay attention only to some features of the firm's nature. We'll analyze only the features, which are the most important for the processes of generating the new knowledge.

Taking as a base R. Coase theory (Coase, 1992: 6), or, saying more precisely, this author's idea about the contract of hiring as a key feature, which characterizes a firm as it is, and a number of the hired workers is a characteristics of the firm size, we guesstimate that for the process of generating the new knowledge this idea is not correct, because of special mechanism of vesting the rights to the new knowledge, which knowledge the employees acquire due to job responsibilities.

In the context of the new knowledge generating, the approach of O. Williamson (1970: 135) should be used not less distinctively. This approach presents "the firm" as one of the ways of transaction organization. A special attention is also to be paid to this author's ideas about the incompleteness of contracts, and about a particular role of the specific assets in the process of choosing a form of contract.

During the working out of the technical University's development strategy, we should also pay attention to the features of its goal-setting.

As we mentioned above, the primary goal for the modern technical University's activities, and specially the goal for the University in provinces, is the development of human and social capital, and the support of the young people's creative activities. It's obvious that the process of generating the new knowledge in the technical University should be a major task for this kind of the creative activity. In other words, the students (first of all - the future competitors for Master's degree), postgraduate students and competitors for Doctor's degree should constantly take part in the processes of generating the new knowledge.

Here we notice an above mentioned peculiarity of the University's social and economic sphere of action. The mentioned propositions of R. Coase theory are not quite correct not only for the process of generating the new knowledge (because of special mechanism of vesting the rights to the new knowledge, which is a result of the special practice of creating and using of the intellectual property). Students and postgraduate students can't be considered as the intra-corporate (if we present University in general as a corporation) actors. This tendency is the most evident for the students, who pay for learning themselves, or, in other words, act as the consumers of the educational services.

This situation is a reason for the ambivalent standing of the students and postgraduate students: each of them in the same time is a representative of the University's internal system and a component of the external environment, having a special contractual relationship with the University. The run of things can be described in the best way if we present a model of the University as of social and economic system of mesolevel (Matkovskyy, 2012: 124).

Organization of the education processes, which's goals list include the salvation of the aforesaid prob- 
lems, should take in account the universally recognized features of the efficient learning process, typical for the education of the $21^{\text {st }}$ century (Coates, 2007: 212). The set of these features includes the cooperative work of the students, cooperation in the workgroups instead of the competition between them. The practical utility of the knowledge that students get is also very important. The subject that the students of the new generation are trying to pursue is getting the information, which's practical utility is evident. Students' motivation level in this situation depends on how clear they understand the ways of using the accumulated knowledge, and the do their best if these ways can be carried out as getting the job in the home region after becoming the graduate.

\section{Technical University as a part of the regional innovation system}

Technical University, which is situated in a region, and has a number of the described above features, is one of the full-fledged parts of the region's innovation system. The University Technopolis is the most efficient as a part of the innovation system.

There is a set of the well-known criteria for choosing a place to situate the technoplos:

- it should be situated in the "mother town" with the population of 150-200 thousand people, or close enough (not more then 30 minutes' journey from it) to simplify the task of supporting its communal services;

- be situated closely to the airport (it does its best if it is close to the international airport) and to the railroad station;

- in the town should be situated a base University, which's task is to train the personnel and to develop the research projects in the field of high technologies;

- it should include a harmonic set of the industrial zones, research institutions and residential settlements;

- it should use a modern informational networks;

- the conditions of the people's leaving should be a factor of promotion the creative and research work, and thinking processes;

- in the work planning should take part all of three interested parties: business, the University and the local government. (Araki, 2000: 136; Yamasaki, 1992: 196).

In the today's conditions, the universities should play a key role in the regional innovation systems. To meet this requirement they should not only present the innovational education and create the startup-enterprises, but also develop the projects in the field of the applied science and engineering for the "traditional" sector of the economy. The University should become not only the educational and research institution, but also a birthplace for the innovations and innovation businesses, in other words - it should transform to a University Technopolis. One of the basic tasks for the development of the higher professional education is students' and teachers' participation in the fundamental and applied research projects. We mean, they should be the direct participants of the process of the new knowledge generating.

A distinctive feature of the University Technopolis is being a polytechnic (multidiscipline) institution. This feature gives a possibility to integrate the activities of the researchers and development engineers to implement the complex projects for the benefit of the region. For example, if the University's staff includes the researchers and development engineers, working in the field of biotechnology; working out the manufacturing equipment; automation of the technological processes; information technology, the University is able to develop the complex projects of the new production systems for the region's agriculture and food production.

The concept of the University Technopolis enables the realization of the most successful models of stateprivate partnership (Sakata, 1991: 96). To realize this model, the participants should achieve a consistency of the agent's interests; taking in account that each of the agents may act in a different economic environment (with different traditions of the institutional organization). That's why in the last years the projects with a state-private partnership are often being presented in a context of the development of the triple helix model 
(University-industry-government) (Shinn, 2002: 15). This model can be successfully used by the University to develop the regional projects.

In this case, the basic functions of the state-private partnership will be the following:

- affecting the economic choice of the private agents, including the situations of the adverse selection;

- partially overcoming the informational asymmetry in the local markets and facilitating the private agents' adaptation for the decision-making under the conditions of the informational asymmetry and incompleteness;

- affect the ratio of the innovators, imitators and laggards in the markets of the scientific and technological products;

- supporting the process of the businesses' adaptation for the reality of macroeconomic disequilibrium;

- being a means for the realization of the state and regional priorities (Nizhegorodtsev, 2014: 7).

Analyzing of the conditions of the Southern Federal District of Russia gives us a possibility to draw a conclusion that the South-Russian State Polytechnic University (situated in Novocherkassk) meets all the requirements to do its best during the creating of the University Technopolis. At the present time the administration is making an attempt to create the University Technopolis on the base of this University.

The efforts of creating the University Technopolis were undertaken during the working out of the SRSPU (NPI) strategic development program. The idea was to solve three basic problems that exist during the University's scientific project development. Fist problem is the lack of the stable relations to the corporative sector of the real economy. The second is the insufficient development of the research and development departments and poor infrastructure for the commercialization of the technologies. The third - a loss of the scientific authorities (in the universities, in comparison with the institutions of the Russian Academy of Sciences), which authorities could have efficiently developed the most innovatively prospective fields of the research. In general, as the index of the scientific efficiency level (total number and quality level of the scientific papers; citation indexes; participation in the international research projects; etc.) shows, the University's scientists are inferior to the ones from the Academy's institutions (Shmatkov, 2011: 6).

\section{Conclusion}

Most of the countries of the Eastern Europe (including Russia) in the last two decades show the tendencies to decreasing a quality level of the human capital. This tendency is very brightly appeared in the provinces.

To overcome the unfavorable tendency the universities and other higher education institutions, which are situated in the provinces, should follow a specific development strategy that's goal is training of the qualified specialists, and to take as the students the local young people, which are going to live and get a job in the region in future.

The strategy should be based on the institutional projecting of the University Technopolis - a social and economic system of mesolevel, in which the students take part in the processes of generating the new knowledge, and that is based on the principles of the state-private partnership and the ideas of triple helix concept.

\section{References}

Anderson, B. A. (2002). Russia faces depopulation? Dynamics of population decline. Popul Environ, Vol. 23, No. 5, p. 437-464.

Araki, K. (2000). Policy Implications of the Concept of Technopole and Japan's Technopolis Programme for Developing Countries. Kousuke: NBK, 136 p.

Barras, R. (1990). Interactive Innovation in Financial and Business Services: The Vanguard of the Service Revolution. Research Policy, Vol. 19, No. 3, p. 215-239.

Becker, G. (1991). Assortative Mating in Marriage Markets. In: G. S. Becker. A Treatise on the Family, ch. 4. Cambridge; London: Harvard University Press, p. 108-134. 
Coase, R. (1992). The Institutional Structure of Production. The American Economic Review, Vol. 82, No. 4, p. $713-719$. Coates, J. (2007). Generational Learning Stiles. NY: LERN, 212 p.

Gerrber, T., Hout, M. (1995). Educational Stratification in Russia during the Soviet Period. The American Journal of Sociology, Vol. 101, No. 3, p. 611-660.

Gomulka, S. (1990). The Theory of Technical Change and Economic Growth. London: Routledge, 238 p.

Gooding, R. (1996). The Theory of Institutional Design, Vol. 36, p. 225-287. Cambridge: Cambridge University Press.

Heleniak, T. (2012). International Comparisons of Population Mobility in Russia. College Park: University of Maryland, $98 \mathrm{p}$.

Kolbachev, E. (2012). Social Efficiency of Organizational and Economic Decisions, which Affect the Development of Higher Education in Russia's Regions. Vestnik of South-Russian State Technical University (NPI), No. 1, p. 118-124 (rus).

Matkovskyy, R. (2012). A meso-level representation of economic systems: a theoretical approach. Munich: MPRA Paper, $124 \mathrm{p}$.

Nizhegorodtsev, R. (2014). The role of universities in the formation of regional clusters and mechanisms of state-private partnership. Innovative prospects of Russia and the World theory and modelling, p. 4-10. Novocherkassk: NPI (rus).

Reichert, S. (2006). Research Strategy Development and Management at European Universities. Brussels: European University Association, 48 p.

Sakata, T. (1991). Chihou Toshi, 21-Seiki e no Kousou (Local cities: Vision for the 21st. Century). Tokyo: NHK Books, $96 \mathrm{p}$.

Shinn, T. (2002). The Triple Helix and New Production of Knowledge: Prepackaged Thinking in Science and Technology. Social Studies of Science, No. 32 (4), p. 599-614.

Shmatkov, V. (2011). University as a Technopolis: A Model of SRSTU Strategic Development for Its Current State. Vestnik of South-Russian State Technical University (NPI), No. 4, p. 7-13 (rus).

Steffen, W., Stephan, J. (2008). The Role of Human Capital and Managerial Skills in Explaining Productivity Gaps Between East and West. Eastern European Economics, Vol. 46, No. 6, p. 5-24.

Tondl, G., Vuksic G. (2003). What makes regions in Eastern Europe catching up? The role of foreign investment, human resources and geography. Bonn: Rheinische Friedrich-Wilhelms-Universität Bonn, 35 p.

Williamson, O. (1970). Corporate Control and Business Behavior: An Inquiry into the Effects of Organization Form on Enterprise Behavior. NY: ABC, 135 p.

Yamasaki, A. (1992). Network-Gata Haichi to Bunsan Seisaku (Industrial Distribution Network and Spatial Dispersal Policy). Tokyo: Taihou-do, 196 p.

\title{
UNIVERSITETAS, KAIP REGIONO VYSTYMO VEIKSNYS: FEDERALINIO PIETU RUSIJOS REGIONO PAVYZDYS
}

\author{
Evgeny Kolbachev \\ Pietų Rusijos valstybinis politechnikos universitetas (Rusija)
}

\section{Santrauka}

Autorius nagrinèjo būdus, kaip įveikti neigiamas žmogiškojo kapitalo degradavimo Rusijos ir Rytų Europos provincijos regionuose tendencijas. Nustatyta, kad svarbus vaidmuo sprendžiant šias problemas tenka technikos universitetams, kurie įsikūrę mažuose regionų miestuose. Universitetų vystymasis turètų remtis tam tikra strategija, kurios tikslas - rengti kvalifikuotus specialistus iš vietos jaunimo, kurie vèliau gyventu ir dirbtų tame pačiame regione. Pateikiami tokios strategijos rengimo reikalavimai, pagrịsti institucinio universitetinio technopolio projektavimo ideja.

PAGRINDINIAI ŽODŽIAI: aukštasis mokslas, žmogiškasis kapitalas, institucinis projektavimas, regionu vystymas, technopolis.

JEL KLASIFIKACIJA: R110, I230, I250 